\title{
THE NODAL WEAR MODEL (NWM) AS AN ALTERNATIVE TO UNDERSTAND THE MECHANISMS OF FLOW AND WEAR IN THE BLAST FURNACE CRUCIBLE
}

\author{
WEZZOWY MODEL ZUŻYWANIA (NWM) JAKO ALTERNATYWA ZROZUMIENIA MECHANIZMÓW \\ PRZEPŁYWU I ZUŻYCIA WYŁOŻENIA GARU WIELKIEGO PIECA
}

\begin{abstract}
The presence of thermocouples in the lining of crucibles has become a general practice in the new construction of blast furnaces. The Nodal Wear Model (NWM) has also emerged as an instrument that, while using experimental data, obtains nodal variables whose experimental measurement is not possible: global coefficient of pig-iron/refractory heat transfer $h_{g-i}^{\text {pig-iron/lining }}$ and nodal temperature $T_{i}$.

Starting from these nodal properties, the wear of the lining or the growth of scabs may be controlled, independently of the mechanisms responsible for them. In the same way, the properties and influence zone of the dead man in the hearth of the blast furnace may be calculated, along with those regions where the fluid is allowed to move without any other restrictions than the ones of the corresponding viscous flow (raceway hearth region).
\end{abstract}

Keywords: Blast furnace, hearth, wear, dead man

Obecność termopar w wyłożeniu garu wielkiego pieca, stało się powszechną praktyką w jego nowoczesnych konstrukcjach. Węzłowy Model Zużycia, staje się narzędziem, które korzystając z danych doświadczalnych, uzyskuje zmienne węzłowe, dla których pomiar bezpośredni jest niemożliwy: całkowity współczynnik przenikania ciepła między surówką, a wyłożeniem ogniotrwałym $h_{g-i}^{\text {surwa/wyoenie }}$ oraz temperaturę węzłową $T_{i}$.

Począwszy od tych własności węzła, zużycie wyłożenia lub powiększanie się narostów, może być kontrolowane, niezależnie od mechanizmów odpowiedzialnych za ich zachodzenie. W ten sam sposób, mogą zostać wyliczone własności i wpływu martwego koksu w garze wielkiego pieca, wzdłuż obszarów, gdzie ciecz może poruszać się bez ograniczeń innych niż te odpowiadające przepływowi lepkiemu (strefa na poziomie dysz w garze pieca).

\section{Introduction}

When describing the mechanisms of wear in the lining, and of metal flow around the dead man (inactive coke) that may be present in the crucible of a blast furnace during its work life, the following considerations and work methods to tackle and try to understand the problem may be found in specialized references [1-3]:

a) These are complex phenomena, in which a great number of variables take part, so a quantitative estimation of wear suffered by the materials and of the density/intensity of the current lines for the melt along the operation life of the crucible are difficult to find. b) On the other hand, it is usual for different corrosion mechanisms to act in parallel, making the evaluation of the participation and importance of each of one of them in the wear process of the lining very difficult [4]. Furthermore, the fluid velocities in the crucible are not homogenous as they depend on the occupation degree (geometry), and characteristics (porosity) and quality of the dead man.

c) Attempts have been made to reproduce and simulate, at a laboratory scale, the operation conditions the hearth of the blast furnace may withstand (with fluid-refractory relative velocities of $0.5 \mathrm{~cm} / \mathrm{s}$ ) and design the furnace lining in accordance to the results

* SCHOOL OF ENGINEERING. UNIVERSIDAD PANAMERICANA. AUGUSTO RODÍN 498, 03920 MÉXICO D.F., MÉXICO

** SID-MET-MAT RESEARCH GROUP. UNIVERSIDAD DE OVIEDO. ETSIMO. INDEPENDENCIA 13, 33004 OVIEDO, SPAIN

*** CENTRO NACIONAL DE INVESTIGACIONES METALÚRGICAS (CENIM/CSIC) AVDA DE GREGORIO DEL AMO, 8. 28040-MADRID, SPAIN

**** AGH UNIVERSITY OF SCIENCE \& TECHNOLOGY, FACULTY OF METAL ENGINEERING \& INDUSTRIAL COMPUTER SCIENCE, A.MICKIEWICZA AV. $30,30-059$ KRAKOW, POLAND 
obtained in samples in contact with corrosive fluids (pig iron and slag).

d) Finally, an attempt is being made to understand the movement of the melt inside the crucible through the use of room temperature physical models, accompanied also by measurements using radioactive tracers to study the characteristics of the pig iron flux in contact with the dead man in the hearth below the nozzles level. Figure 1 shows a 3D finite element simulation of the melt flow, where the complexity of the results makes it difficult to estimate wears.

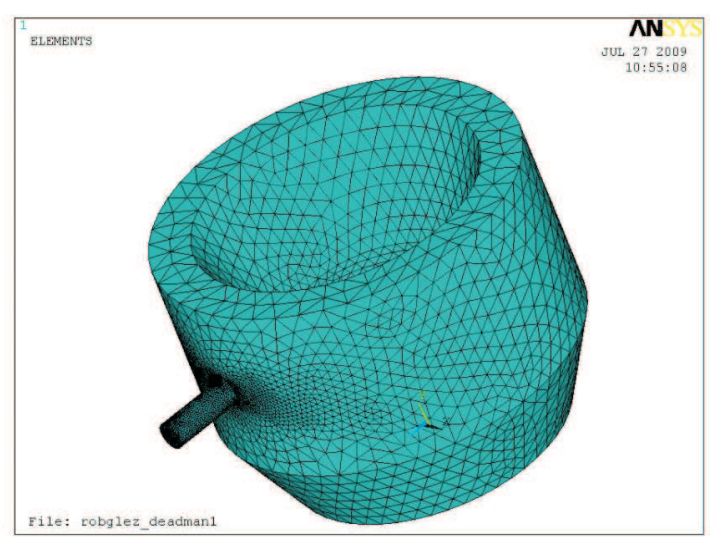

(a)

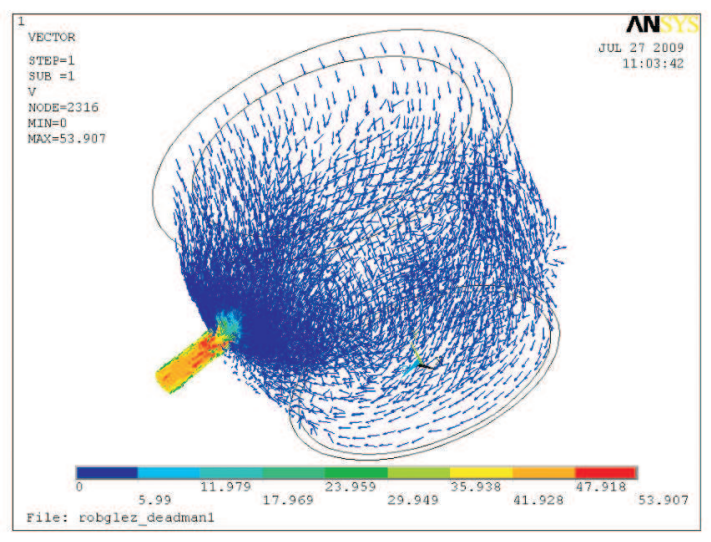

(b)

Fig. 1. 3D finite element simulation of melt flow in a dead man hearth, showing mesh and element distribution (a) and fluid velocity (b)

A fact that differentiates the NWM in respect to other practices aimed at understanding this problem, is that both wear and scab growth, as well as dead man characteristics, circulation velocities of the fluids (pig iron and slag), furnace operation (production) parameters, geometric design characteristics and nature of the crucible materials, are not independent variables and, the values each one of them may reach, slightly or strongly determine all the others. For example, when trying to explain the behavior of refractory linings submitted to corrosive action (pig iron and slag), different wear mechanisms or physical characteristics or geometries the dead man may adopt inside the hearth are described, as if these results were not a consequence of a determined operation (production) practice, under which, the blast furnace has been demanded to produce for specific periods of time.

The novelty of the NWM is to admit that wear, blast furnace production and dead man physical and geometric characteristics are connected and dependant phenomena. On the other hand, the variables that may explain the bidimensional (2D) behavior of an specific section of the blast furnace crucible, according to the NWM, are reduced to the following four properties:

- Global heat transport coefficient between pig iron and lining $h_{g-i}^{\text {pig-iron/lining }}$.

- Nodal temperature at the pig iron-refractory interface $T_{i}$.

- Nodal position variation (increase or decrease) of the abscissa in the pig iron-refractory interface $\Delta x_{i}$.
- Nodal position variation (increase or decrease) of the ordinate in the pig iron-refractory interface $\Delta y_{i}$.

While the temperature of the melted components inside the hearth of the blast furnace (tapping temperature $T_{\infty}$ ) is an important parameter in order to control the furnace operation, the temperature at the refractory-melt interface (nodal temperature $T_{i}$ ) or the global heat transport coefficient between the pig iron and the lining $h_{g-i}^{\text {pig-iron/lining }}$ aren't variables accessible to direct experimental determination [5]. Nevertheless, in all situations studied so far, experimental data supports the hypothesis, theories and developments of the NWM, though the characteristics of problems laid out in blast furnace crucibles, bottom, walls and roofs of electric furnaces, or copper metallurgy PS convertor linings, have only a few points in common [6,7].

Though, as already mentioned, both $T_{i}$ and $h_{g-i}^{\text {pig-iron/lining }}$ are not variables accessible through direct experimentation, they may be indirectly determined if the crucible is equipped with a temperature measurement system $\left(T \leqslant 600^{\circ} \mathrm{C}\right)$ and the corresponding algorithm to determine the position of isotherms inside the lining throughout the furnace operation life. The flowchart and input and output variables that take part in the thermal $2 \mathrm{D}$ problem posed in the NWM are shown in Figure 2 and Table 1, respectively, in order to study specific sections of the crucible in a blast furnace (Figure 3). Particularly, under "zero wear" conditions the values of both $\Delta x_{i}$ and $\Delta y_{i}$ would be null. Nevertheless, at the end 
of three, six or nine months of operation, the situation would have changed and each node at the interface would have experimented a negative variation (corrosion) or a positive one (growth). The usual procedure would be to calculate the geometric and thermal parameters at the pig iron-refractory interface nodes in a 2D section after 9 months, using as starting point, in the convergence iterations to be executed, the $\Delta x_{i}, \Delta y_{i}, T_{i}$ and $h^{\text {pig-iron/lining }}$ values, obtained for this same section of the crucible, for example, after a 6 months operation period (Figure 2).

Input - output variables in the $2 \mathrm{D}$ section study of the NWM of the blast furnace hearth

\section{INPUT VARIABLES}

- Tapping temperature, $T_{\infty}$ (mean value between time periods studied).

- Geometry of hearth at the beginning the periods studied.

- Lining materials conductivity.

- Mean temperature of water cooling between time periods studied.

- Mean temperature of oil cooling between time periods studied.

- $h_{\text {oil }}^{f}$, global transport coefficient in the oil at the bottom of the hearth.

- $h_{\text {water }}^{f}$, global transport coefficient in the water at the walls of the hearth.

- $h_{g-i}^{\text {pig-iron/lining }}$, nodal global transport coefficient across pig-iron refractory interface.

\section{OUPUT VARIABLES}

- Nodal temperatures, $T_{i}$, across the pig-iron refractory interface.

- Isotherms inside the refractory lining.

- Nodal wear values: $\Delta x$ or $\Delta y$.

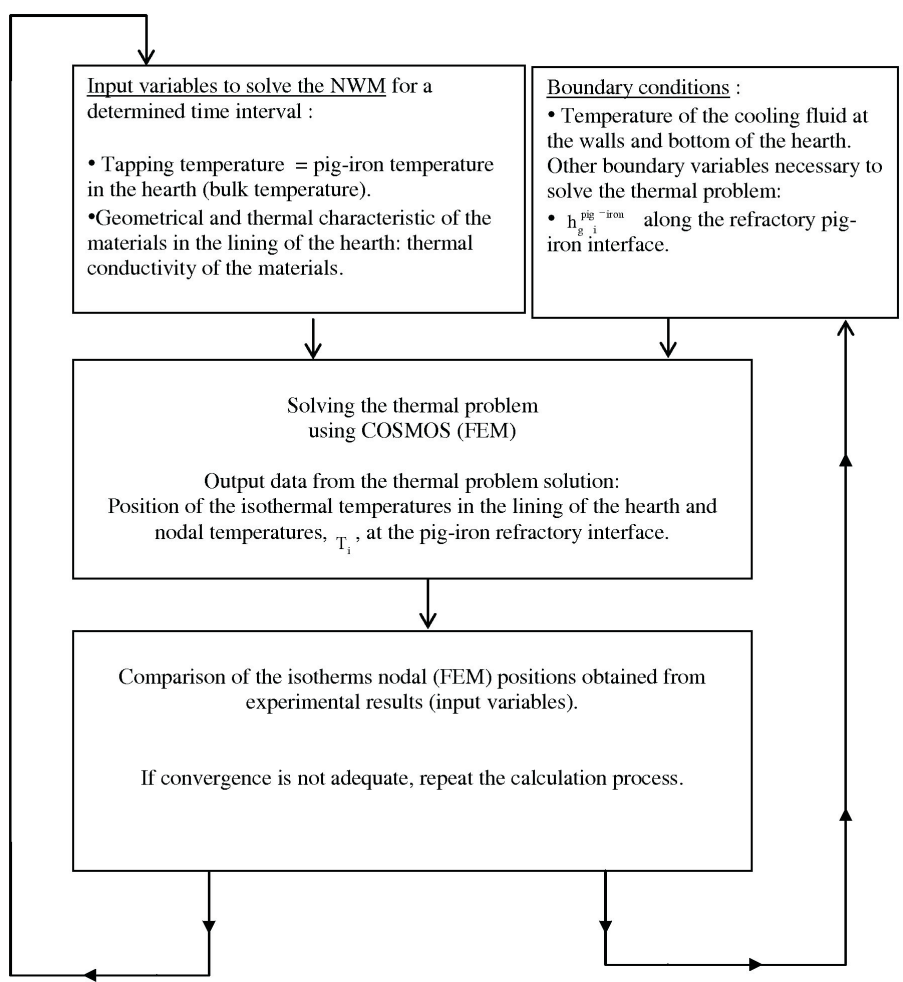

Fig. 2. Determination of nodal properties: $h_{g-i}^{\text {pig-iron/lining }}$ and $T_{i}$ of different $2 \mathrm{D}$ sections of a blast furnace hearth 


\section{Corrosion of materials in the crucible of the blast furnace and the NWM}

If the NWM is considered, the wear-growth of scabs in $2 \mathrm{D}$ sections of the materials in contact with corrosive fluids at the blast furnace hearth, the profiles to be drafted after long operation periods, may be considered dependant of the following variables:

- Global heat transport coefficient between pig iron and lining $h_{g-i}^{\text {pig-iron/lining }}$,

- equivalent thermal conductivity of the materials at the lining $\bar{\lambda}_{\text {lining }}$,

- mean values of the global heat transport coefficient from the cold zone of the refractory towards the cooling exterior system $h_{g}^{r}$, and

- nodal geometric variables of either wear or growth $\left(\Delta x_{i}\right.$ and $\left.\Delta y_{i}\right)$ referred to the initial geometry of the pig iron-refractory interface at "zero wear" conditions.

Thus, according to the NWM, the behavior of a 2D section S1 (Figure 3) of the crucible along a period of time, $\Delta t$, of the blast furnace campaign, would be defined in the following way:

$$
\text { Model - 2D - S1 }\left(h_{g-i}^{\text {pig-iron/lining }} ; \bar{\lambda}_{\text {lining }} ; h_{g}^{r} ; \Delta x_{i} ; \Delta y_{i}\right)
$$

Depending on the operational characteristics of the blast furnace (load and gas movement, pig iron/slag production and quality of raw materials), a value of the $h_{g-i}^{\text {pig-iron/lining }}$ parameter will be established that, besides being a nodal variable, may also show considerable variations along the melt-refractory interface (walls, bottom or corners of the crucible), corresponding, for example, to the S1 section in Figure 3. In other words, the operation characteristics of the furnace are related to the $h_{g-i}^{\text {pig-iron/lining }}$ value along the pig iron-refractory interface.

On the other hand, the design of the crucible depends on the geometry, nature and distribution of the materials used during construction. Besides physical, mechanical and chemical characteristics, it may be stated that one of the critical factors (though not the only one) in the lining design is the equivalent thermal conductivity $\bar{\lambda}_{\text {lining. }}$. In this way, by taking into account this physical property, the model includes (equation 1) a representation of the variable that best represents the products used during construction.

\section{TH1}

G1A

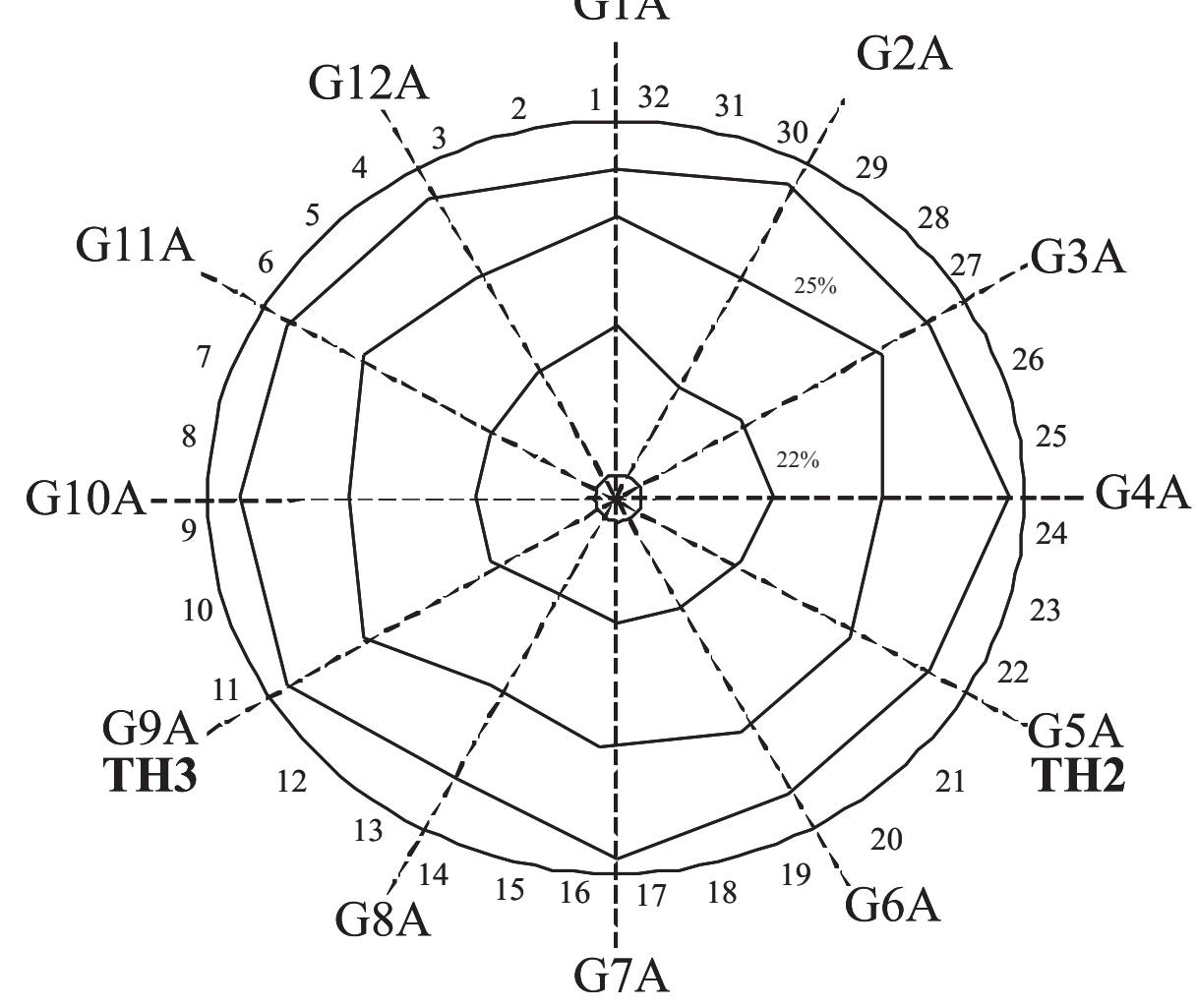

Fig. 3. Position of the twelve sections and tap-holes (TH-1, TH-2 and TH-3) for a blast furnace hearth with $10.0 \mathrm{~m}$ of diameter at the tuyeres level. Porosity $\varepsilon(\%)$ of the dead man (inactive coke) in the hearth is indicated 
The geometrical variables that play a roll in the nodal wear (or growth), are represented in the 2D model by the $\Delta x_{i}$ and $\Delta y_{i}$ parameters.

Also, one of the variables with special consequence in the study of this process is related, according to the NWM, with the cooling system characteristics acting on the cold face of the refractory: major differences would be observed when using forced cooling by water, air or oil. The $h_{g}^{r}$ parameter makes reference to the numerical value of the global heat transport coefficient between the refractory and the cooling fluid being used.

Depending on the nature and thickness of materials used during the blast furnace construction, cooling at the beginning of the campaign may result inefficient: the elevated capacity to evacuate heat by the external cooling system may be baffled by the high thermal resistance of the crucible refractories or by a production capacity well below the furnace nominal standard.

On the other hand, for some metallurgical installations, experimental identification of isotherms in the lining and variables product of the NWM, may be calculated through one single expression, just as indicated by equation 1 . Though, for the blast furnace, the calculations are more complex [8,9].

Along the interface of the refractory with the melt in the hearth of the blast furnace, there isn't a unique value for $h_{g-i}^{\text {pig-iron/lining }}$. Generally, different values for the global heat transport coefficient are reached at the bottom, corners and walls of the crucible. Being more precise, not even at the characteristic length of both the corners nor the bottom, the magnitude of $h_{g-i}^{\text {pig-iron/lining }}$ is a constant, due to the fact that the transition of nodal values from a corner towards a wall, takes place not in an abrupt or discontinuous way, but in a progressive one. Because of this, at least three similar expressions of equation 1 should be used to define the $2 \mathrm{D}$ section of a blast furnace: one for the wall, one for the bottom and, finally, one for the corners.

Finally, another aspect that complicates the definition of the crucible with an expression in accordance to equation 1 , is the fact that during the campaign, changes in production practices may cause disruptions in the value of $h_{g-i}^{\text {pig-iron/lining }}$ and, thus, from that specific moment in the operation life of the furnace, modifications in the wear mechanisms of the crucible may occur.

\section{Characteristics of the dead man (inactive coke) in the crucible of the blast furnace and the NWM}

When production in the blast furnace is started and the blowing-in process takes place, all of the available volume from the collecting-vat and hearth is occupied by coke. At the tuyeres level, the furnace is slowly heated by the partial combustion of the coke. This material at the mentioned level is consumed and substituted by the same material from the upper inlet until reaching a threshold temperature at the hearth, that will allow the ferric load to be added $[2,10]$.

Once the proportion of ferric-reduction load feeded to the furnace reaches stationary conditions, the situation of the coke after a three-month operation period won't be very different to the one represented by Figure 4-a: dead man resting over the base of the hearth.

Taking as starting point the $T_{i}$ and $h_{g-i}^{\text {pig-iron/lining }}$ values, product of the NWM analysis in one of the crucible sections (Figure 2), Table 2 presents a briefing of expressions used to calculate the most representative variables at different zones of the crucible throughout the work campaign of the furnace (Figure 4).

The symbol $\varepsilon$ in equation 2 of Table 2 corresponds to the porosity at the center of the hearth and may be obtained from the production of pig-iron $A\left(\mathrm{t} \cdot \mathrm{hr}^{-1}\right)$, slag production $E$ (kg.t pig-iron ${ }^{-1}$ ), crucible surface $S$ (m) and pressure variation referred to a one hour time unit $(d P / d t)$, consequence of the furnace operation (decrease during tapping and raise when the tap-hole is sealed) [11].

The nodal surface velocity $v_{s-i}$ of the fluid around coke particles in contact with the bottom, corners or wall of the crucible are calculated from the following nodal properties of the fluid:

- Nodal temperature $T_{i}$,

- viscosity $\mu_{i}$,

- density $\rho_{i}$,

- Prandtl number $\operatorname{Pr}_{i}$,

- Nusselt number $N u_{i}$ and

- global heat transport coefficient between the melt and the refractory $h_{g-i}^{\text {pig-iron/lining }}=h_{g-i}$ in expression 3 of Table $2[12,13,14]$. 

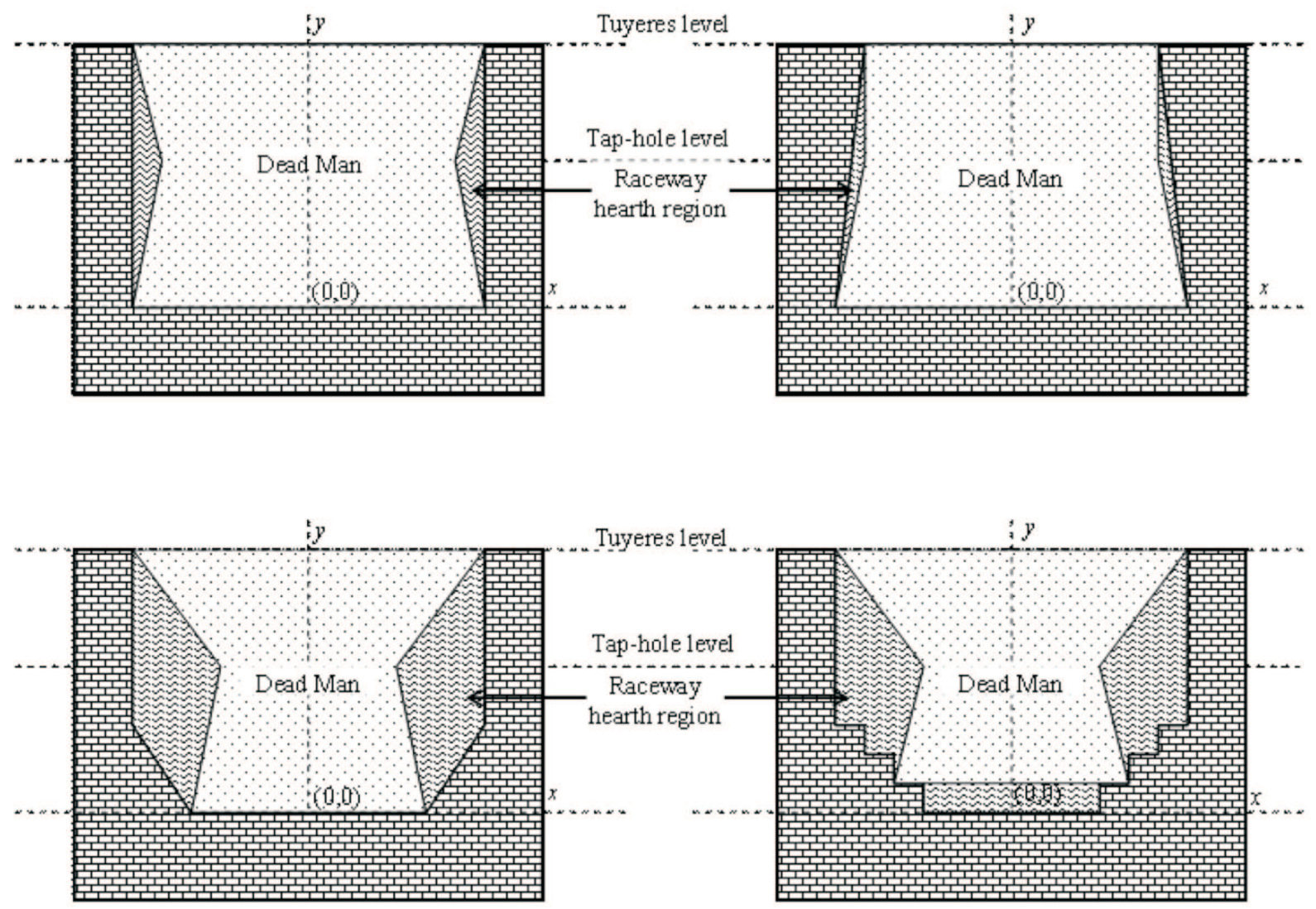

Fig. 4. Different possibilities in design and position of the inactive coke region (dead man and hearth raceway) in a blast furnace

TABLE 2

Equations to calculate the porosity, mean value of coke particles size and superficial velocity of fluids in the blast furnace hearth

Porosity at the center $(0,0)$ of the static bed of inactive coke particles (Figure 3)[11].

$$
\varepsilon_{\text {centro }}(\%)=\left[\frac{0.0981 A\left(1+\frac{E}{1000}\right)}{S\left(\frac{d P}{d t}\right)}\right] 100
$$

Nodal superficial velocity, $v_{s-i}\left(\mathrm{~m} \cdot \mathrm{s}^{-1}\right)$. Ranz-Marshall-Kitaiev equation [12-14].

$$
v_{s-i}=\left[\frac{h_{g-i}^{2} \rho_{i}^{0.5} \mu_{i}^{-0.5}}{(C-R M K)^{2} T_{i}^{0.60}}\right]^{1 / 1.30}\left[\frac{0.60 \operatorname{Pr}_{i}^{0.33}}{N u_{i}-2.0}\right]^{1 / 1,30}
$$

Mean value of coke particles size distribution at the static bed, $\bar{D}_{p}$. Kitaiev equation [12].

$$
\bar{D}_{p}=\left[(C-K) \frac{v_{s-i}^{0.9} T_{i}^{0.30} L}{h_{g-i}}\right]^{1 / 0.75}
$$

Median superficial velocity, $\bar{v}_{s-i}$, and porosity, $\varepsilon$, at bed. Ergun equation [15-17].

$$
\frac{\Delta P}{L}=\frac{150 \mu_{i} \bar{v}_{s-i}}{\bar{D}_{p}^{2}} \frac{(1-\varepsilon)^{2}}{\varepsilon^{3}}+\frac{1.75 \rho_{i} \bar{v}_{s-i}^{2}}{\bar{D}_{p}} \frac{(1-\varepsilon)}{\varepsilon^{3}}
$$


The mean size of coke particles $\bar{D}_{p}$ at the region of the dead man inside the hearth, is a function of $v_{s-i}$; $T_{i} ; h_{g-i}^{p i g-i r o n / l i n i n g}=h_{g-i}$ and of the characteristic linear dimension of the system analyzed $L$ : bottom, corner or wall of the crucible in equation 4 of Table 2 [12].

Finally, the mean surface velocity $\bar{v}_{s-i}$ and porosity $\varepsilon$ at the bed of inactive coke particles, are related with the Ergun equation through the following variables: $\bar{D}_{p}$, $\mu_{i}, \rho_{i}, L$ and $\Delta P$ (pressure variation in the crucible due to tapping or sealing of the tap-hole) as indicated by equation 5 in Table 2 [15-17].

Figure 4 shows some of the different options that the influence zones of the dead man may present, along with regions fitted for the free circulation of the melt (raceway of the hearth). In order to estimate the thickness of these regions where the melt will freely circulate, without the barriers imposed by the bed of coke particles, the following equation must be considered:

$$
\left[\mu_{i}\left(T_{i}\right)-\mu_{i}\left(T_{\infty}\right)\right] \Delta e=C
$$

Where $\mu_{i}\left(T_{i}\right)$ represents the viscosity of the melt in contact with the wall, corner or bottom of the crucible, $\mu_{i}\left(T_{\infty}\right)$ is the viscosity at the interface of the dead man influence zone and melt separation, $\Delta e(\Delta x$ o $\Delta y)$ is the thickness of the raceway of the hearth and $C$ is a constant which characterizes the region of the crucible being studied.

\section{Experimental results}

Table 3 and Figure 5 show the work conditions in a blast furnace crucible under "zero wear" lining supposition. This configuration suggests that the inactive coke is partially leaned against the bottom of the crucible $[18,19]$. Table 4 and Figure 6 indicate the corresponding values, calculated by the method described in Table 1 and Figure 2, for $T_{i}$ and $h_{g-i}^{\text {pigiron/lining }}$ at different locations (nodes) of both the wall and the bottom of the crucible.

Operation conditions of the blast furnace considering "zero wear" at the walls and bottom of the crucible

\begin{tabular}{|c|c|}
\hline Daily production & $6000 \mathrm{~T}$ of pig-iron and $1500 \mathrm{~T}$ of slag \\
\hline Tappings per day & 12 \\
\hline Tapping time (min) & 76 \\
\hline Time between tappings (min) & 44 \\
\hline Coke characteristics $\left(\bar{D}_{p}\right)(\mathrm{mm})$ & $50 \mathrm{~mm}(0.050 \mathrm{~m})$ \\
\hline $\begin{array}{l}\text { Length of inactive coke (dead man) at the bottom of the } \\
\text { crucible }(\mathrm{m})\end{array}$ & $D^{*}(\mathrm{dm})=7.43 \mathrm{~m}$ \\
\hline Tap-hole height (m) & $h_{\text {tap-hole }}=2.96 \mathrm{~m}$ \\
\hline Crucible diameter at nozzle level $(\mathrm{m})$ & $D_{\text {crucible }}=10.03 \mathrm{~m}$ \\
\hline Crucible height at nozzle level (m) & $h_{\text {nozzle }}=4.91 \mathrm{~m}$ \\
\hline Inactive coke porosity at the center of the crucible $(\varepsilon)$ & $22.77 \%$ \\
\hline Ranz-Marshall-Kitaiev constant $(C-R M K)$ & 495.05 \\
\hline Kitaiev constant $(C-K)$ & 8.36 \\
\hline $\begin{array}{c}\text { Thermal characteristics of the crucible } \\
\text { Mean thermal conductivity of materials at the wall of the crucible } \\
\text { Mean thermal conductivity of materials at the bottom of the crucible } \\
\text { Tapping temperature, } T_{\infty}\end{array}$ & $\begin{array}{c}\text { HAB1-2 model, Figure } 5 \\
\bar{\lambda}_{\text {refractory }}=9.39 \mathrm{~W} \cdot \mathrm{m}^{-1} \cdot \mathrm{K}^{-1}(\text { Wall }) \\
\bar{\lambda}_{\text {refractory }}=6.65 \mathrm{~W} \cdot \mathrm{m}^{-1} \cdot \mathrm{K}^{-1}(\text { Bottom }) \\
1500{ }^{\circ} \mathrm{C}(1773 \mathrm{~K})\end{array}$ \\
\hline
\end{tabular}




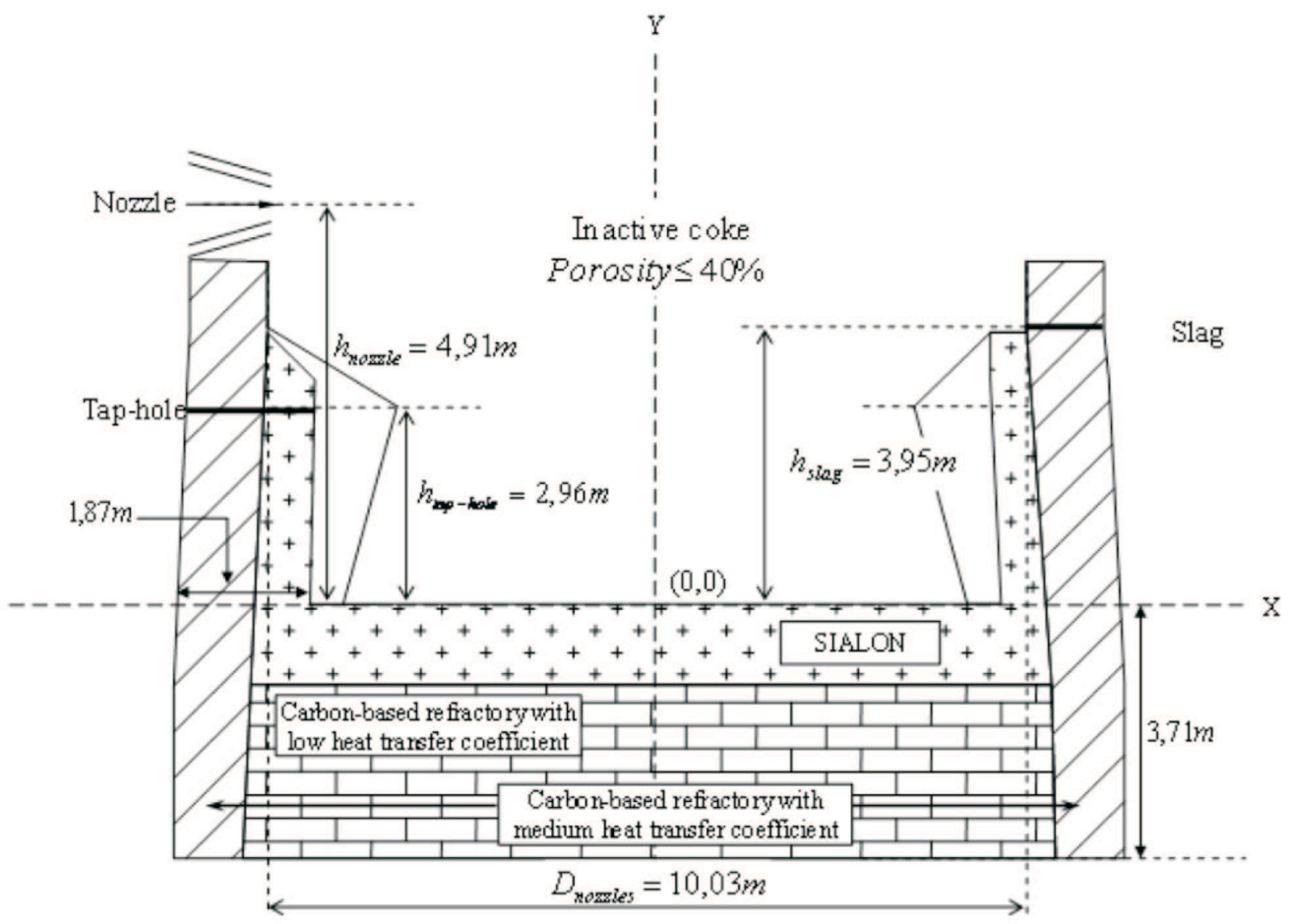

Fig. 5. HAB1-2 crucible and materials used in its lining

Temperatures $\left(T_{i}\right)$ and global heat transport coefficients at some positions (nodes) at the bottom and wall of the crucible $\left(h_{g-i}^{\text {pig-iron/lining }}\right)$

\begin{tabular}{|c|c|c|c|}
\hline Node & Position $(x ; y)$ & $h_{g-i}^{\text {pig-iron/lining }}\left(\mathrm{W} \cdot \mathrm{m}^{-2} \cdot \mathrm{K}^{-1}\right)$ & Temperature, $T_{i}\left({ }^{o} \mathrm{C}\right)$ \\
\hline 0 (bottom) & $(0.00 ; 0.00)$ & 40,0 & 1434 \\
\hline 1 (bottom) & $(-0.67 ; 0.00)$ & 40,5 & 1434 \\
\hline 2 (bottom) & $(-1.34 ; 0.00)$ & 41,0 & 1433 \\
\hline 3 (bottom) & $(-2.01 ; 0.00)$ & 42,0 & 1432 \\
\hline 4 (bottom) & $(-2.67 ; 0.00)$ & 42,5 & 1432 \\
\hline 5 (bottom) & $(-3.01 ; 0.00)$ & 43,5 & 1431 \\
\hline 6 (bottom) & $(-3.34 ; 0.00)$ & 45,0 & 1431 \\
\hline 7 (bottom) & $(-3,68 ; 0.00)$ & 75,0 & 1453 \\
\hline 8 (bottom) & $(-4.35 ; 0.00)$ & 105,0 & 1467 \\
\hline 9 (corner) & $(-5.01 ; 0.00)$ & 53.0 & 1383 \\
\hline 10 (wall) & $(-5.01 ; 0.85)$ & 94.8 & 1439 \\
\hline 11 (wall) & $(-5.01 ; 1.69)$ & 94.8 & 1440 \\
\hline 12 (wall) & $(-5.01 ; 2.54)$ & 93.5 & 1445 \\
\hline $9 *$ (Taphole) & $(-5.01 ; 2.96)$ & 91.0 & 1460 \\
\hline
\end{tabular}


Using the calculated nodal properties $\left(T_{i}\right.$ and $h_{g-i}^{\text {pigiron/lining }}$ ) along the pig iron - refractory interface, certain characteristics of the particles at the bed of inactive coke may also be calculated: porosity $(\varepsilon)$, coke particles mean size $\left(\bar{D}_{p}\right)$, global heat transport coefficients between the coke and the melt $\left(h_{g-i}^{\text {cokelmelt }}\right)$ and/or superficial speed of the melt in contact with the coke $\left(v_{s-i}\right.$ or $\left.\bar{v}_{s-i}\right)$. Furthermore, the position of nodes $4^{*}, 5^{*}$ and $6^{*}$ at the interface of the static bed of coke and the melt may also be defined, along with the position of node 13 , which is an indication of the influence of the coke in the zone II of the blast furnace crucible (Figure 6).

Table 5 presents the characteristics of the static bed of coke particles at zone I (below the tap-hole) and Table 6 corresponds to zone II (above the tap-hole), shown at Figure 6.

TABLE 5

Mean coke particle size $\left(\bar{D}_{p}\right)$, superficial speed $\left(v_{s-i}\right.$ o $\left.\bar{v}_{s-i}\right)$ and porosity of the particle bed $(\varepsilon)$ at Zone I of the crucible

\begin{tabular}{|c|c|c|c|c|c|c|}
\hline Node & $\bar{D}_{p}(\mathrm{~m})$ & $v_{s-i}\left(\mathrm{~m} \cdot \mathrm{s}^{-1}\right)$ & $\varepsilon(\%)$ & Node & Position $(x ; y)$ & $\bar{v}_{s-i}\left(\mathrm{~m} \cdot \mathrm{s}^{-1}\right)$ \\
\hline 0 & 0.0500 & $1.175 \cdot 10^{-2}$ & 22.77 & $0^{*}$ & $(0.00 ; 2.96)$ & $3.082 \cdot 10^{-2}$ \\
\hline 1 & 0.0496 & $1.184 \cdot 10^{-2}$ & 22.88 & $1^{*}$ & $(-0.67 ; 2.96)$ & $3.105 \cdot 10^{-2}$ \\
\hline 2 & 0.0492 & $1.192 \cdot 10^{-2}$ & 23.04 & $2^{*}$ & $(-1.34 ; 2.96)$ & $3.128 \cdot 10^{-2}$ \\
\hline 3 & 0.0485 & $1.211 \cdot 10^{-2}$ & 23.35 & $3^{*}$ & $(-2.01 ; 2.96)$ & $3.175 \cdot 10^{-2}$ \\
\hline 4 & 0.0481 & $1.218 \cdot 10^{-2}$ & 23.51 & $4^{*}$ & $(-2.67 ; 2.96)$ & $3.198 \cdot 10^{-2}$ \\
\hline 5 & 0.0272 & $1.236 \cdot 10^{-2}$ & 31.76 & $5^{*}$ & $(-3.01 ; 1.95)$ & $4.924 \cdot 10^{-2}$ \\
\hline 6 & 0.0088 & $1.263 \cdot 10^{-2}$ & 54.17 & $6^{*}$ & $(-3.34 ; 0.85)$ & $11.541 \cdot 10^{-2}$ \\
\hline 7 & 0.0003 & $1.791 \cdot 10^{-2}$ & 78.25 & - & - & $16.365 \cdot 10^{-2}$ \\
\hline 8 & 0.0001 & $11.766 \cdot 10^{-2}$ & 98.82 & - & - & $107.511 \cdot 10^{-2}$ \\
\hline
\end{tabular}

TABLE 6

Mean superficial speed $\left(\bar{v}_{s-i}\right)$, porosity $(\varepsilon)$ and global heat transfer coefficients $\left(h_{g-i}^{\text {cokelfluid }}\right)$ of nodes at the inactive coke influence zone for Zone II of the crucible

\begin{tabular}{|c|c|c|c|c|}
\hline Node & Position $(x ; y)$ & $h_{g-i}^{\text {cokefluid }}\left(\mathrm{W} \cdot \mathrm{m}^{-2} \cdot \mathrm{K}^{-1}\right)$ & $\varepsilon(\%)$ & $\bar{v}_{s-i}\left(\mathrm{~m} \cdot \mathrm{s}^{-1}\right)$ \\
\hline $0^{* *}$ & $(0.00 ; 3.85)$ & 93.6 & 22.77 & $5.691 \cdot 10^{-2}$ \\
\hline $1^{* *}$ & $(-0.67 ; 3.85)$ & 94.8 & 22.88 & $5.715 \cdot 10^{-2}$ \\
\hline $2^{* *}$ & $(-1.34 ; 3.85)$ & 96.0 & 23.04 & $5.757 \cdot 10^{-2}$ \\
\hline $3^{* *}$ & $(-2.01 ; 3.85)$ & 98.4 & 23.35 & $5.844 \cdot 10^{-2}$ \\
\hline $4^{* *}$ & $(-2.67 ; 3.85)$ & 99.6 & 23.51 & $5.886 \cdot 10^{-2}$ \\
\hline $5^{* *}$ & $(-3.01 ; 3.85)$ & 100.4 & 23.57 & $5.904 \cdot 10^{-2}$ \\
\hline $6^{* *}$ & $(-3.34 ; 3.85)$ & 101.2 & 23.67 & $5.930 \cdot 10^{-2}$ \\
\hline $7^{* *}$ & $(-3.68 ; 3.85)$ & 102.0 & 23.77 & $5.956 \cdot 10^{-2}$ \\
\hline $8^{* *}$ & $(-4.35 ; 3.85)$ & 103.6 & 23.96 & $6.008 \cdot 10^{-2}$ \\
\hline
\end{tabular}




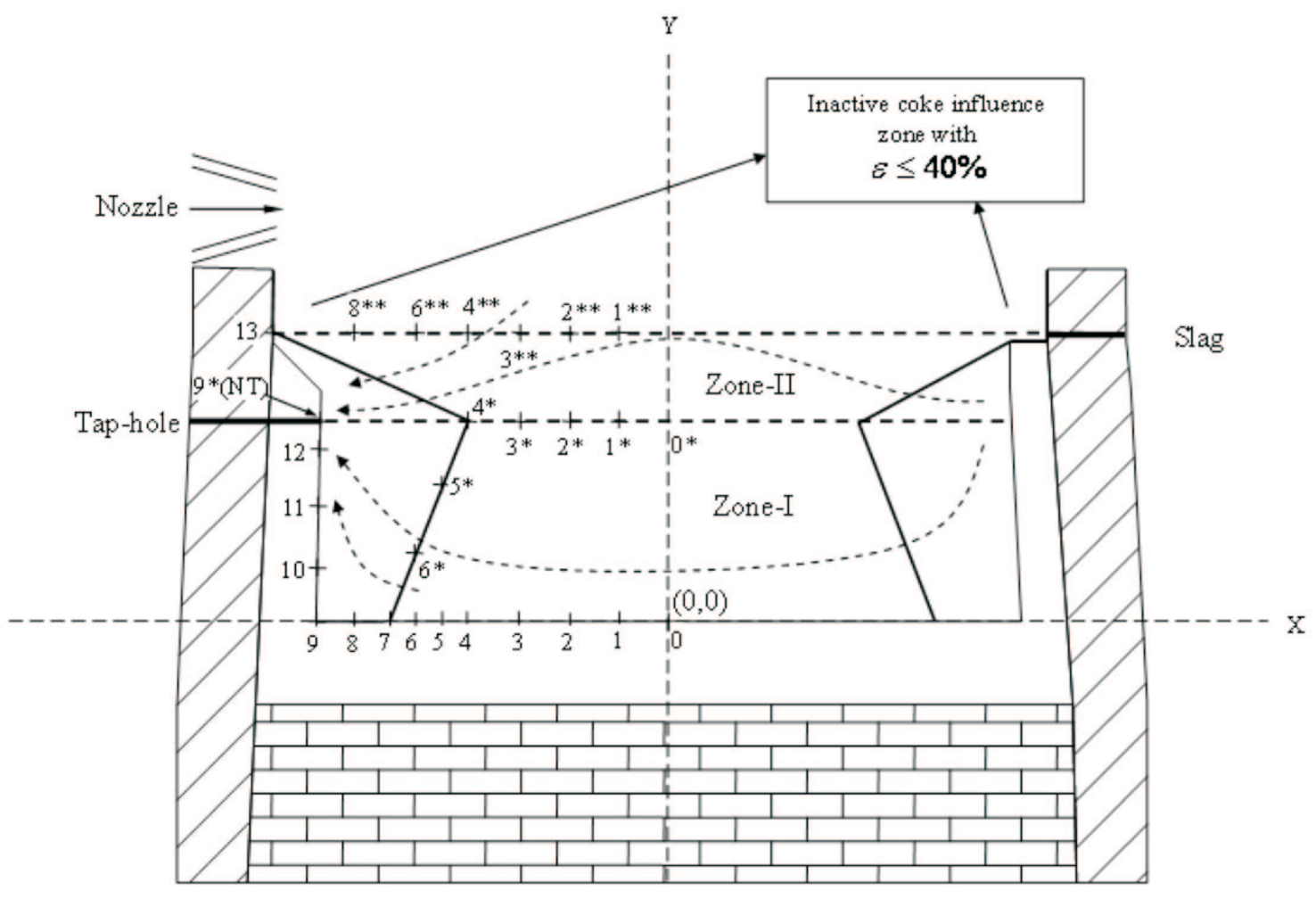

Fig. 6. Inactive coke influence zone and positions where the flow/porosity of the crucible may be measured

\section{Conclusions}

The nodal wear model represents an efficient complement to work with and interpret experimental isotherms at the lining of any given 2D section of a blast furnace crucible, and the possibility to obtain the following:

1. The resulting differential wear of the refractories that constitute the working lining of the furnace crucible at any specific zone: walls, corners or bottom.

2. In the same way noticeable wear at corners or central part of the crucible may be detected in a 2D section. Formation of protective scabs at the walls or bottom may also be detected.

3. The erosion of the lining reflects in the values of $T_{i}$ and of $h_{g-i}^{\text {pig-iron/lining }}$, independently from the fact that the wear mechanism acting is of the chemical or mechanical type.

4. Starting from the $T_{i}$ and $h_{g-i}^{\text {pig-iron/lining }}$ values, in a determined 2D section of the crucible, coke properties may be estimated, along with the major or minor influence of the dead man region with respect to the zones where the melt freely circulates (raceway of hearth).

5. Considering the results in different $2 \mathrm{D}$ sections of the crucible for an specific moment in the operation life of the furnace, a 3D representation may be pos- sible, including both of the refractory lining profiles as well as those corresponding to the dead man influence zone.

\section{Acknowledgements}

The authors wish to thank the Ministry of Education and Science (MEC): MAT2003-00502, the Ministry of International Affairs and Cooperation (MAEC): MAEC-AECI-B/1629/04; B/2884/05; $\mathrm{B} / 5814 / 06, \mathrm{~B} / 7648 / 07$ and the CSIC-Madrid (Spain) for making the scientific and technological cooperation between CENIM/CSIC and Oviedo University possible through the "Associated Unit".

This work was based on fruitful cooperation between the CSIC-Madrid (Spain) and the AGH University of Science \& Technology.

\section{REFERENCES}

[1] Y. O m or i, Blast furnace phenomena and modelling, Ed. Elsevier, England, 345-352, 395-405 (1987).

[2] F. Habashi, Handbook of Extractive Metallurgy. Metal Industry: Ferrous Metals I, Ed. Wiley-VCH, Germany, 57-104 (1997).

[3] J.P. B e n n e t t, J.D. S m it h, American Ceramic Society, Ceramic Transactions 125, 135-154 (2001).

[4] L.F. Verdeja, J.P. S a n cho, A. B allester, Materiales Refractarios y Cerámicos, Síntesis, 19-22; 156-176, Madrid (2008). 
[5] M.A. R o m e r o, J. J i m é n e z, J. M o c hó n, J.L. M e n é nd e z, A. For m o s o, F. B u e n o, Rev. Metal. Madrid 36, 1, 40-46 (2000).

[6] R. Parra, L.F. Verdeja, M.F. B a rbé s, C. G o ñi, V. B a z á n, JOM 57, 10, 29-36 (2005).

[7] C. G o ñ i, M.F. B a r bé s, V. B a zá n, E. B r a n $\mathrm{d}$ a $1 \mathrm{e} \mathrm{z}$ e, R. P a r r a, L.F. V e r d e j a, J. Ceram. Soc. Jpn 114, 8, 665-668 (2006).

[8] H.B. Lünge n, H.P. R üther, G. C lixby, G. $\mathrm{C}$ a s s e 11 a, Investigations on blast furnace wear phenomena especially in the heart, European Commission. Technical Steel Research. EUR 19347 EN, 193 (2000).

[9] K. Mülhei m s, W.D.N. Pritchard, J.M. S teiler, M. Schult e, Wear blast furnace heart, European Commission. Technical Steel Research. EUR 20109 EN, 272 (2002).

[10] J.P. S a n cho, L.F. Verdeja, A. B a 11 e s t e r, Metalurgia Extractiva: Procesos de obtención, Síntesis, Madrid 2000, 55-74 (2000).

[11] S.A. Zaïmi, M.J. Venturni, D. S e rt, Rev. Metall-Paris, Journées Sidérurgiques ATS-2002, 99, 11, 18-19 (2002).

[12] O. Havelange, G. D a n loy, J.M. Venturin i, H. P i e r r e t, H.P. R ü th e r, O. Mi e l e n z, H. Kö c hn e r, J.A. A l ex a nd e r, J.R. Post a nd, G.
C 1 i x by, Determination of coke bed voidage in the blast furnace hearth, European Commission. Technical Steel Research. EUR 20942 EN, 194 (2004).

[13] G. D a n loy, M. Falzetti, A. Formoso, E. $\mathrm{H} \mathrm{e} \mathrm{r} \mathrm{f} \mathrm{u} \mathrm{r} \mathrm{th,} \mathrm{J.} \mathrm{Ve} \mathrm{g} \mathrm{a,} \mathrm{Modelling} \mathrm{of} \mathrm{gas} \mathrm{and} \mathrm{char} \mathrm{flows}$ at high PCI through experimental and theoretical studies of the raceway and the dead man. European Commission. Technical Steel Research. EUR 20094 EN/DE, 224 (2002).

[14] C.B. A 1 c o c k, Principles of pyrometallurgy, Academic Press, London, 98-99 (1976).

[15] A. B a 11 e s te r, L.F. Verdeja, J.P. S a n c ho, Metalurgia Extractiva: Fundamentos, Síntesis, Madrid, 235-238 (2000).

[16] D.R. P o i r i e r, G.H. G e i g e r, Transport phenomena in materials processing, TMS, Pennsylvania, 93-98 (1994).

[17] J. Ji méne z, J. Mo chon, J. S a inz de Ayala, ISIJ Int. 44, 3, 518-526 (2004).

[18] $\mathrm{M}^{a}$. F. B a r bé s, E. M a rin a s, E. B r a nd a le ze, R. Parra, L.F. Verdeja, G.A. C a s tillo, R. C o 1 á s, ISIJ Int. 48, 2, 134-140 (2008).

[19] R. Martín Duarte, M.A. B a rbés, E. Marin a s, N. A y a la, J. M o chón, L.F. Verdeja, F. G a r c í a, Rev. Metal. Madrid 45, 4, 295-304 (2009). 